\title{
Front Matter: Volume 9310
}

, "Front Matter: Volume 9310," Proc. SPIE 9310, Frontiers in Biological Detection: From Nanosensors to Systems VII, 931001 (9 March 2015); doi: 10.1117/12.2183941

SPIE. Event: SPIE BiOS, 2015, San Francisco, California, United States 


\title{
Frontiers in Biological Detection: From Nanosensors to Systems VII
}

\author{
Benjamin L. Miller \\ Philippe M. Fauchet \\ Brian T. Cunningham \\ Editors
}

7 February 2015

San Francisco, California, United States

Sponsored and Published by

SPIE 
The papers included in this volume were part of the technical conference cited on the cover and title page. Papers were selected and subject to review by the editors and conference program committee. Some conference presentations may not be available for publication. The papers published in these proceedings reflect the work and thoughts of the authors and are published herein as submitted. The publisher is not responsible for the validity of the information or for any outcomes resulting from reliance thereon.

Please use the following format to cite material from this book:

Author(s), "Title of Paper," in Frontiers in Biological Detection: From Nanosensors to Systems VII, edited by Benjamin L. Miller, Philippe M. Fauchet, Brian T. Cunningham, Proceedings of SPIE Vol. 9310 (SPIE, Bellingham, WA, 2015) Article CID Number.

ISSN: 1605-7422

ISBN: 9781628414004

Published by

SPIE

P.O. Box 10, Bellingham, Washington 98227-0010 USA

Telephone +1 3606763290 (Pacific Time) · Fax +1 3606471445

SPIE.org

Copyright (c) 2015, Society of Photo-Optical Instrumentation Engineers.

Copying of material in this book for internal or personal use, or for the internal or personal use of specific clients, beyond the fair use provisions granted by the U.S. Copyright Law is authorized by SPIE subject to payment of copying fees. The Transactional Reporting Service base fee for this volume is $\$ 18.00$ per article (or portion thereof), which should be paid directly to the Copyright Clearance Center (CCC), 222 Rosewood Drive, Danvers, MA 01923. Payment may also be made electronically through CCC Online at copyright.com. Other copying for republication, resale, advertising or promotion, or any form of systematic or multiple reproduction of any material in this book is prohibited except with permission in writing from the publisher. The CCC fee code is $1605-7422 / 15 / \$ 18.00$.

Printed in the United States of America.

Publication of record for individual papers is online in the SPIE Digital Library.

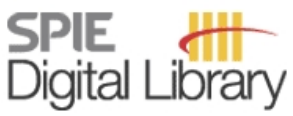

SPIEDigitallibrary.org

Paper Numbering: Proceedings of SPIE follow an e-First publication model, with papers published first online and then in print. Papers are published as they are submitted and meet publication criteria. A unique citation identifier (CID) number is assigned to each article at the time of the first publication. Utilization of CIDs allows articles to be fully citable as soon as they are published online, and connects the same identifier to all online, print, and electronic versions of the publication. SPIE uses a six-digit CID article numbering system in which:

- The first four digits correspond to the SPIE volume number.

- The last two digits indicate publication order within the volume using a Base 36 numbering

system employing both numerals and letters. These two-number sets start with 00, 01, 02, 03, 04, $05,06,07,08,09,0 A, 0 B \ldots$. OZ, followed by 10-1Z, 20-2Z, etc.

The CID Number appears on each page of the manuscript. The complete citation is used on the first page, and an abbreviated version on subsequent pages. 


\title{
Contents
}

\author{
$\checkmark$ Authors \\ vii Conference Committee
}

SESSION 1 PHOTONIC CRYSTALS, WAVEGUIDES, AND INTERFEROMETRY I

931003 Optical waveguide biosensor based on cascaded Mach-Zehnder interferometer and ring resonator with Vernier effect [9310-4]

931004 An optical biosensor for detection of pathogen biomarkers from Shiga toxin-producing Escherichia coli in ground beef samples [9310-5]

\section{SESSION 2 PHOTONIC CRYSTALS, WAVEGUIDES, AND INTERFEROMETRY II}

931006 Examining small molecule: HIV RNA interactions using arrayed imaging reflectometry [9310-7]

931007 A novel antibody immobilization strategy for optical biosensors [9310-8]

SESSION 3 RAMAN, PLASMONICS, AND FLUORESCENCE

9310 OA Plasmonic nanoparticle interaction with cell membrane for diagnostic applications [9310-10]

9310 OB Smartphone fluorescence spectroscopy [9310-13]

\section{SESSION 4 OTHER ADVANCED TECHNIQUES}

9310 OD Laser cross-linking protein captures for living cells on a biochip [9310-2]

9310 OF Quantifying DNA and proteins using laser-induced thermophoresis [9310-15] 
Proc. of SPIE Vol. $9310931001-4$

Downloaded From: https://www.spiedigitallibrary.org/conference-proceedings-of-spie on 26 Apr 2023 Terms of Use: https://www.spiedigitallibrary.org/terms-of-use 


\title{
Authors
}

Numbers in the index correspond to the last two digits of the six-digit citation identifier (CID) article numbering system used in Proceedings of SPIE. The first four digits reflect the volume number. Base 36 numbering is employed for the last two digits and indicates the order of articles within the volume. Numbers start with 00, 01, 02, 03, 04, 05, 06, 07, 08, 09, 0A, 0B...0Z, followed by 10-1Z, 20-2Z, etc.

\author{
Adams, Peter, 04 \\ Arikady, Akshata, OA \\ Baldeck, Patrice L., OD \\ Banisadr, Afsheen, 04 \\ Carter, Jared A., 07 \\ Chaimayo, Wanaruk, 06 \\ Chen, Hai-Wen, OD \\ Chen, Yih-Fan, OF \\ Cunningham, Brian T., OB \\ Das, Sumana, OA \\ Graves, Steven, 04 \\ Harika Villa, Krishna, OA \\ $\mathrm{He}$, Jian-Jun, 03 \\ Hegde, Gopalkrishna M., OA \\ Jiang, Xianxin, 03 \\ Konnur, Manish C., OA \\ Lamoureux, Loreen, 04 \\ Li, Mingyu, 03 \\ Lifson, Mark A., 07 \\ Lin, Che-Kuan, OD \\ Lin, Chih-Lang, OD \\ Lin, Chuen-Fu, OD \\ Miller, Benjamin L., 06, 07 \\ Montano, Gabriel, 04 \\ Moxley, Rodney, 04 \\ Mukundan, Harshini, 04 \\ Pan, Ming-Jeng, OD \\ Roy Mahapatra, D., OA \\ Song, Jinyan, 03 \\ Stromberg, Zachary, 04 \\ Tan, Yafang, OB \\ Tang, Longhua, 03 \\ Vasireddi, Ramakrishna, OA \\ Wang, Chih-Hsuan, OF \\ Yu, Hojoeng, OB \\ Yu, Li-Hsien, OF
}


Proc. of SPIE Vol. $9310931001-6$

Downloaded From: https://www.spiedigitallibrary.org/conference-proceedings-of-spie on 26 Apr 2023 Terms of Use: https://www.spiedigitallibrary.org/terms-of-use 


\title{
Conference Committee
}

\author{
Symposium Chairs
}

James G. Fujimoto, Massachusetts Institute of Technology

(United States)

R. Rox Anderson, Wellman Center for Photomedicine, Massachusetts General Hospital (United States) and Harvard School of Medicine (United States)

Program Track Chair

Brian Jet-Fei Wong, Beckman Laser Institute and Medical Clinic (United States)

\section{Conference Chairs}

Benjamin L. Miller, University of Rochester Medical Center (United States)

Philippe M. Fauchet, Vanderbilt University (United States)

Brian T. Cunningham, University of Illinois at Urbana-Champaign (United States)

Conference Program Committee

Xudong Fan, University of Michigan (United States)

Laura Maria Lechuga, Catalan Institute of Nanoscience and Nanotechnology (Spain)

Frances S. Ligler, U.S. Naval Research Laboratory (United States)

Michael J. Sailor, University of California, San Diego (United States)

Oliver G. Schmidt, Leibniz-Institut für Festkörper- und Werkstoffforschung Dresden (Germany)

Christopher C. Striemer, Adarza BioSystems, Inc. (United States)

Sharon M. Weiss, Vanderbilt University (United States) 
Proc. of SPIE Vol. $9310931001-8$

Downloaded From: https://www.spiedigitallibrary.org/conference-proceedings-of-spie on 26 Apr 2023 Terms of Use: https://www.spiedigitallibrary.org/terms-of-use 